\title{
American Variety of English Language
}

\author{
Mamedzade Sevinj ${ }^{1}$ \\ ${ }^{1}$ Odlar Yurdu University, Baku, Azerbaijan \\ Correspondence: Mamedzade Sevinj, Odlar Yurdu University, Baku, Azerbaijan. E-mail: \\ mamedzade-1982@mail.ru
}

Received: July 3, 2015 Accepted: July 26, 2015 Online Published: September 29, 2015

doi:10.5539/ijel.v5n5p159 URL: http://dx.doi.org/10.5539/ijel.v5n5p159

\begin{abstract}
In linguistics, dialect is the language that is used in certain area. Even when two people speak the same language, they may not speak it in the same way. In linguistics, we use the terms dialect and variety to describe the particularities of the speech of any regional or social group. Although all speech (and all language) belongs to one variety or another, the speech of the dominant class is popularly referred to as the standard and the speech of minority groups are labeled as dialects. Knowing the history of the different varieties of a language can tell us a lot about the history of a language, a region, and a people.

In this article, our main purpose is not to study all the dialect varieties of English language, but to analyze the specific events which are against to grammatical rules and which cause problems while speaking in English or while translating. There are some grammatical forms that don't exist in Standard English language, but they are used in spoken language in every part of the country. The example of this grammatical construction is the dialect variety of English speaking countries.
\end{abstract}

Keywords: Standard English, Black English, non-standard language, spoken American language

\section{American Dialects}

The formation of American Standard underwent the influence of minorities of languages, but its starting point was the English language of the early $17^{\text {th }}$ century. We speak of the national variant of English in America. American English shows a lesser degree of dialects than British English due to some historical factors.

There are three main American dialects, such as New England (Eastern type), Southern dialect and Common (General) American dialect which is used in the other parts of the country. Because the variety of American English is based on the words from these dialects, it is true that these dialects are differing grammatically, phonetically and lexically from one another. We have to point out that all the words and their pronunciations that are used in New England are not accepted in the same way in the southern part of the country. The people in New England are mainly the people who came from England and southern people consist of the people who came from Africa as slaves. General American is the form of speech used by the radio and television. It is mostly used in scientific, cultural and business intercourse.

According to S. K. Thomas, "We have a lot of materials to analyze and to study the varieties of American and British English, such as the linguistic map of the United States and Canada." (Thomas, 1936) As there are 50 states in the U.S.A. each of them has its own accent and pronunciation style.

American English varieties reflect the cultural landscape of the United States. While Standard American English is arguably the most visible dialect of American English, many other varieties - such as Boston English, New York City English, Appalachian English, California Surfer Dude \& Valley Girl English, and Chicago English-are also spoken in the United States.

In 1949 Hans Kurath explored 18 linguistic regions in the southern Carolina and in the states on the coast of Atlantic Ocean. He divided them into three groups and made the eastern geographical map of the United States. According to this map the dialect variety in the United States is divided into six regions (Kurath, 1949).

\section{1) Eastern New England}

It is the area on the coast of Mississippi River. In this area the main characteristic feature is that they pronounce differently the letter "a" in some words as [a:], e.g., fast [fa:st], past [pa:st], grass [gra:s] and so on. They pronounce the letter "o" as [o] in words such as hot [hot], top [top]. The letter "r" (car [ka:], hard [ha:d] ) is not 
pronounced at the end of the words. We suppose that it is because of the influence of England and English people to that part of the U.S.A who settled here in the past. They try to follow the Standard English pronunciation.

\section{2) The dialect of New York City}

It is the part of eastern New England dialect. It has to be pointed that in different parts of New York City there are different pronunciations. We think that, as New York is the main city of industry and it is the most famous city in the U.S.A., there are a lot of different nations in this city. That is why they influence to each other and to their speech. For this reason we suppose that there are dialect variations in New York City, e.g., curl [kə:l], soil [sə:l] and so on. The right pronunciation is [soil].

\section{3) Mid Atlantic dialect}

It is the eastern part of Pennsylvania, northern Midland and the southern part of New Jersey. The main characteristic feature is that they don't round their lips while pronouncing the words hot [hnt], top [t $\Lambda \mathrm{p}]$. They pronounce the vowel a [ei] as [æ] in the words fast [fæst], ask [æsk], grass [græs].

\section{4) Western Pennsylvania dialect}

The main feature of this linguistic area is that it accepts all the rules of general American pronunciation. It means that they pronounce "a" as [æ], in the words such as past [pæst] and path [pæs]. They pronounce " $\mathrm{r}$ " [r] sound everywhere as in word car [ka:r].

\section{5) Southern Upland dialect}

Sometimes it is difficult to point the borders of this area. Virginia and southern Carolina coasts belong to this area. In several regions of this area the pronunciation is the same as in New England. The main characteristic feature of this dialect is the absence of [r] sound as in hard [ha:d], far away [fa: ə'wei]. However, the letter "o" is pronounced as $[\Lambda]$, the letter "a" as [æ] as in $[\mathrm{h} \Lambda \mathrm{t}]$ and [græs]. Another specific feature of this dialect is that the diphthong [au] in the word "out" is pronounced as [æu] - out [æut]. Some words consisting of one syllable omits the last consonant as in words last [las], kept [kep], find [fain] and so on (Kurath, 1928).

\section{6) General American dialect}

This dialect is characterized according to the following specifics:

- The letter "a" is pronounced as [æ], e.g., fast [fæst]

- The rounded "o" is pronounced as unrounded $[\Lambda]$ as in hot $[\mathrm{h} \Lambda \mathrm{t}]$.

General American dialect is mainly spoken in New-York and Southern New-York. For example, in Philadelphia people use the word combination "baby coach', at the same time they use and understand the word combination "baby carriage". This dialect keeps [r] sound during the pronunciation the words as in world [wə:rld].

General American dialect is used in 2/3 part of the U.S.A. (Thomas, 1925).

In order to differentiate the specific characteristics of various dialects, first of all we have to get information about the roots of the people who lived here. That's why the historical-geographical map of the U.S. was created after the studies of the people from different regions. It was founded that 1291 families firstly came to New England and 687 families came to Virginia from England (Kurath, 1928). The studies show that these families that came from England kept their dialects and pronunciation style. Despite the changes they tried to keep the original form of some words.

The main purpose of this article is to find out the main ways of the progress of the American variety of English language.

It is not the right way to divide the people of this country to several dialects according to their speaking. It is not the way to solve all the problems because there are some words, idioms and word combinations which need to be defined. For example, if one person in Boston wants "tonic" we have to understand that this person wants soft drink or if one person wants in northern region to park his car in the street he may use "to park a car". But in other regions this term is "rank a car", in southern states it is "file a car". All these terms have the same meaning (Kurath, 1928).

We can even find different varieties in a small region. For instance, in the tribes of New England different varieties of one word were defined, e.g., earthworm, angleworm, fisher worm, rain worm. All these words have the same meaning. There are several words or terms which are understood in all parts of America. 
The interest to American English caused to the creation of American dialect society. In 1889 the magazine named "The dialect notes" was published in this society. In 1919 H.L. Mencken published the book which was named "American language". There were too many varieties in that book. Several years later American English became the main problem of the day and different kinds of linguistic books were published after that (Mencken, 1919).

\section{Black English}

One variety of American English that can be heard throughout the country and in a lot of popular music and media is African American English. In this part of the article we would like to mention about African American English which influenced to English language not less than other varieties. African American English goes by many other names including Black English, African American Vernacular English, African American Language, and Ebonics (although the term "Ebonics" is often avoided by linguists because of its negative connotations).

Black English accent - in other words the language of black people in the U.S. was not so interesting and important to linguists. Nowadays they have a great interest to this accent. Despite that Black English is non-standard language, it is different from non-standard language and the English of white people. According to Mc. Denis there is no any factor that differentiates black people from white. But, according to their pronunciation you may differentiate them; who is black, who is white or who is from Midland.

A writer in the North American review for June, 1888, mentions certain words in use among the Negroes of the southern states, and inquiries after their origin. The words are buccra (white man), brottus (used in Georgia in request for small present, as, "What are you going to give for brottus?", and lagniappe (used in new Orleans in somewhere the same as brottus). The derivation of brottus may be similar to that of lagniappe, from the English perhaps, but one cannot speak with certainty.

American linguist Steward made a lot of efforts to explore the differences between Black English and Standard English. Some words like goeber (peanut), juke (box) and others entered to the English language dictionary. The word goeber is, I think of, African origin. In Haussa (West African tongue), guya is ground-nut (Chamberlain, 1888). Such kinds of words like uh-huh (yes) is understood in the U.S. either by black or white people. However, people from Great Britain don't understand and don't accept these words (Steward, 1996).

Prof. Wolfram shows us that the final sound [t] in some words is omitted in Black English. For example: list [lis], missed [mis], left [lef], act [æk]. We have to point that in black English other sounds like [p,k,d] may be omitted too, e.g., desk [des], find [fain], cold [koul] and so on. In some words the final consonant preceding the plural suffix is not pronounced as in kids [ki:z] (Wolfram, 1972).

There are also some differences in sentence making in Black English. They don't pay attention to grammar rules while speaking. For instance; I am going to visit him. In Black English: I gonna visit him.

One difference between African American English and Standard American English can be found in the mental dictionary, or lexicon. Along with the lexical items shared by speakers of other English varieties, African American English also has many vocabulary items that are culturally specific, things like: kitchen - noun. The hair at the nape of the neck that tends to be difficult to straighten as in "Sheila need to comb her kitchen cause it's looking kinda rough." Or "Sheila need to perm that kitchen back there (Moody, 2011).

Black English is very famous in California and San-Francisco regions. The main reason of this was the golden mines of XIX century and then the progress of agriculture. The cheap work of black people was used here in factories and plants many years.

Likewise, the rules of phonology, morphology, and grammar that characterize African American English are often different from Standard American English. For example, the verbs is and are can be omitted in certain places in African American English but not in Standard American English:

\section{He $\emptyset$ reading the newspaper.}

They $\varnothing$ on the computer.

[Editor's Note: In linguistics, the symbol Ø is used as a place-holder for a word that has been left out]

Black English as the variety of English language is not only the English of black people, but also is the main language of white people. Black English was formed within the standards and rules of English language. Some American scientists (e.g., L. William) insist on that Black English is the part of American English and can't be divided into regional dialects because this language is the spoken variety of one ethnic group of black people in an appropriate place. There is no difference between north-eastern urban Black English (New-York), Southern Ruhr Black English and so on. According to American linguist Claudia Mitchell Black English is the variety of English 
language and at the same time is the national dialect. The main differences of Black English from other varieties of English language are phonetical and grammatical differences (Mitchell, 1974).

Different ceremonies of black people also influenced to American English. Black peoples' church with its customs, traditions and ceremonies gave a lot of new terms to American English. American variety of English attracted the attentions of several linguists. They found out that different immigrants have come to the northern towns of the country and they brought several foreign languages with them. In that situation they felt need to a unique language which could be understood by everyone. That need caused the creation of American variety.

We have to tell that Black English played an important role in creation of American English. Because the first terms in American English, such as, break, ragtime, woogie came from Black English, from jazz music of black people (in 1920s). Soon term from "rock and roll" music were added to American English. For example: hard rock, rockabilly.

There are some other terms which have an interesting history, e.g., to lay an egg (to perform something for the first time). Another example connected with scene- play down (an important dialogue on scene). New American terms were created in different parts of science. For instance, the creation of telephone gave a new term "hello" to American English. An inventor A.G. Bell created a new tool which answered automatically. That tool naturally gave a sound "ahoy" and Edison changed that sound to poetic "hallow". We use this word every day in our lives.

Television programs, radios, the presidents' speeches also influence to the creation of American terms. For example, one of the presidents of the U.S., J. F. Kennedy mainly used [r] sound in his speech even in the word idea of. He pronounced as idea[r]of.

C. Swigard, the head of very famous church in Louisiana in the U.S. used to say Newnited States [nju:naitid] instead of United States. All these examples show that different language varieties, social groups, religious terms and others influence to the formation and improvement of one language. In XVII century [r] and [æ] sounds were forbidden in Southern England. So, in America the words neither and either are pronounced as [ni:ðə] and [i:ðə], in England they are pronounced as [naiðə] and [aiðə]. In America the word fall [fo:l] is accepted as autumn [o:tm] in England.

Regarding to such kinds of words we can explore other different varieties of New England. Here are some words which have the same meaning in American and British English.

\begin{tabular}{|l|l|}
\hline American English & British English \\
\hline Buttered eggs & Scrambled eggs \\
\hline chemist & druggist \\
\hline ale & beer \\
\hline apartment & flat \\
\hline baggage & luggage \\
\hline Baby carriage & pram \\
\hline automobile & motor car \\
\hline subway & underground \\
\hline barbers & haircut \\
\hline soft drinks & minerals \\
\hline
\end{tabular}

\section{Summary}

Because there are many linguistic differences between African American English and Standard English, it has been difficult for linguists to reach a consensus regarding the variety's origins. Although the ultimate ancestry may be lost to history, most linguists acknowledge that African American English developed as a result of enslaved Africans coming into contact with speakers of British English dialects on plantations in the U.S. during the 17th, 18th, and early19th centuries. Even today, African American English and Southern White Vernacular English, spoken by many in the U.S. South, share linguistic similarities (Moody, 2011).

While differentiating American and British English we can meet a question: Is English in England or English in America more conservative? To our mind, the language is the same language, but people change the elements of language during their speech and create different varieties. It depends on the character of the person who uses the word.

Ernest Weekly says: "100 or 50 years later there will be more new terms and words in English language. English language will accept not only the linguistic words, but also new words from different spheres." (Weekley, 1986) 


\section{References}

Chamberlain, A. F. (1888). Negro Dialect. Science, 12(284), 23-24. http://dx.doi.org/10.1126/science.ns-12.284.23

Kurath, H. (1928). The Origin of Differences in Spoken American English. Modern Philology, 25(4), 385-395. http://dx.doi.org/10.1086/387724

Kurath, H. (1949). A Word Geography of the Eastern United States. Ann Arbor, MI: University of Michigan Press.

Mencken, H. L. (1919). American language.

Mitchell, C. (1974). Black English.

Moody, S. (2011). The diversity of English in America. Popular linguistics, 1.

Steward. (1996). Differences between Black English and Standard English.

Thomas, S. K. (1925). American English.

Thomas, S. K. (1936). Pronunciation in Upstate New York. American Speech, 11(2), 142-144. http://dx.doi.org/10.2307/451701

Weekley, E. (1986). Old and New English.

Wolfram. (1972). West Indian accent.

\section{Copyrights}

Copyright for this article is retained by the author(s), with first publication rights granted to the journal.

This is an open-access article distributed under the terms and conditions of the Creative Commons Attribution license (http://creativecommons.org/licenses/by/3.0/). 